\title{
METHODICAL APPROACH TO DETERMINE THE INFLUENCE OF ECONOMIC ACTIVITY IN THE REGION ON THE STATE OF THE TERRITORIAL ENVIRONMENT OF THE TERRITORY
}

\author{
Olena Berezina ${ }^{*}$, Maksim Petrovskiy
}

Cherkasy State Technological University, Cherkasy, Ukraine

\begin{abstract}
The goal of this research work is the formation of methodological approach of ecological factor assessment impact on the development level of territorial economic systems. This article presents the quality indicators of the development of socio-economic areas, which reflect total level and the extent of human impact on the natural environment characterizing the level of economy influence (economic activities) on the environment. This article suggests the approach to the calculation of Eco-intensity indicator and general air pollution dynamics in Ukraine, regarding regions, type of economic activities/industries. The research studies the comparative evaluation and the characteristics of the ecological status of the territories. It was determined that for the period from 2005 till 2012 the emissions of pollutants into the atmosphere from stationary and mobile pollution sources are being gradually reduced due to the decreasing level of production enterprises, which were the main polluters of the atmosphere. According to the types of economic activity, the measurements of Eco-intensity emissions of pollutants and carbon dioxide indicated that the biggest indices were in energy distribution, mining and processing industries.
\end{abstract}

Keywords: ecological factor, natural environment, socio-economic development

\section{Introduction}

The assessment of the current position, the level of economic development and its impact on the natural environment require the use of modern economic tools, particularly the construction and use of indicators with the aim of providing information support for planning processes and decision making in the regulation of sustainable socio-economic development at regional and sectorial levels (Danilishin et al., 1999). The currently proposed systems of indicators (FDES, 2013) most closely reflect the general socio-economic trends caused by transformation processes that occur in economy. At the same time, the ecological component of economic system, in which the most negative consequences of long-term economic decisions are reflected, is not taken into account during the development of policy documents (Bobylev and Zakharov, 2012). Therefore, the problems of environmental considerations of economic development focus on research areas to determine the basic parameters of quality assessment of socioeconomic regions development in the context of sustainable growth. A number of resource-intensiveness indicators are widely used in modern practice for assessing the level of sustainable development of territories (Granovska, 2008), which in some cases is defined as Eco-intensity or intensity of pollution, eco- and resource capacity. For example, on the basis of SEEA (System of Environmental-Economic Accounting), environmental indicators are included to characterize the interaction of economy and environment in the area of research (SEEA, 2012). Also in the proposals of the $\mathrm{OECP}$, the World Bank and in analytical practice, there are different interpretations of the indicator of natural capacity (Granovska, 2008). Primarily, we may include: energy, water and material consumption, metal capacity, specific emissions and discharges, specific waste production and consumption, which reflect both the value of output and population or land area of the region. At that point, as a rule, two levels of indicators of environmental capacity are determined: a macroeconomic level which is considered in the framework of national or regional economy; industrial level - which may be represented at national and regional levels. In addition, indicators of environmental capacity can be determined at sub-regional level, but also at micro level, i.e. at level of enterprises and other economic entities (Berezina and Cherevko, 2014).

\section{Material and methods}

Ecological-economic analysis and assessment of the territory were based on the methods of primary data collection and data processing (for collection and processing data for eco-analyses), statistical, comparative geographical, mathematical methods (for calculation the indicators of Eco-intensity, Eco-capacity, Eco-productiveness and regional estimating), methods for systematic and logical generalization, settlement and constructive methods (for systematization and analyses of the scientific approaches of assessing the impact of ecological factor on the development of territorial economic systems). In the research, the materials of the State Administration of Ecology and Natural Resources and the State Statistics Service of Ukraine have been used. The general research methodology is based on the concept of sustainable development of the territory (Kates, Parris and Leiserowitz, 2005).

\section{Results and discussion}

From our point of view, the indicator of natural capacity consolidates (generalizes) the quality indicator of socio-economic development of the territory, which reflects the general level and the extent of human impact on the natural environment. The indicators of Eco-intensity or intensity of pollution are determined by the volume of pollution per unit of output or square (Khlobystov and Chernofva, 2008). We suggest that the indicators of eco capacity present the strength of environment influence to economic activity, primarily on nature, including humans. In general, the indicators of Eco-intensity as eco capacity itself reflect the influence of all kinds of pollution or indicate a certain impact. 
Indicators of resource capacity are the most informative indicators for the determination of anthropogenic pressures to all natural resources. They are expressed through specific indicators such as the proportion of disturbed land in total land area of the region or the proportion of space occupied by the wastes storage, including illegal ones, in a total land area of the region or the total amount (weight) of accumulated waste, including hazard class. Also, using resource capacity indicators, we may fix the size of the total consumption of each resource output per unit (Danilishin et al., 1999).

In general, the indicators of environmental capacity characterize the efficient functioning of any economic system: type, level and quality of economic development. Among economic criteria, the reduction of natural capacity of the economy is an effective criterion for sustainable development.

Figure 1 shows the interrelation of indicators that characterize the level of impact on the environment.

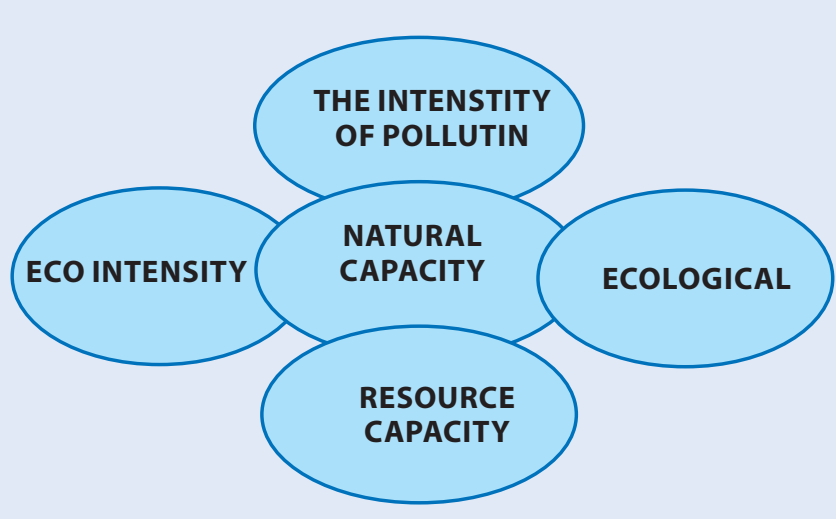

Figure 1 The indicators of environmental interrelation capacity of economy

In the international system of environmental-economic accounting, these indicators (pollution intensity or Eco-intensity) for different types of environmental loads are calculated as indicators of environmental capacity per unit of value added (Calculating eco-efficiency indicators, 2012). The dynamics of these indicators suggests the possibility of sectors to have the greatest impact on the environment and on economy in general, increasing the value added per unit and costs for environmental impact or reduce these costs per unit of value added. This is a very important factor in the decision of environmental problems of the regions with the unique natural resources and rich natural resource base, where the economic development and social welfare depend on the intensity of natural resources use.

Indicators calculation of environmental capacity, reflecting the pressure of the economy on the environment and on the human being can be determined on the basis of the following ratios (Calculating eco-efficiency indicators:..., 2010):

1. Eco-intensity E industries with regard to environmental pressure $(p)$ is defined as the environmental pressure per unit of added value:

$$
E_{i}=\frac{q_{i}^{p}}{v_{i}}
$$

where:

$v_{i} \quad-$ added value, produced by industry $i$

$q_{i}^{p} \quad$ - environmental pressure $(p)$ industry $(i)$

Eco-intensity reflects the specific amount of negative impact on the environment or a unit area. The impurities are generally considered to be harmful contaminants which are contained in the emissions and discharges of enterprises, various gases, wastes of production and consumption. Indicator Eco-intensity allows establishing the interrelation between industries and the damage caused to the environment of the production and commercial operations of enterprises. The goal of this is to identify the most polluting types and sectors of economic activity in a region.

2. Eco productiveness of a region, taking into account the environmental pressure $(p)$ is defined as the sum of value-added generated for a unit of costs for environmental impact:

$$
E_{p}=\frac{v_{i}}{q_{i}^{p}}
$$

3. Eco capacity $E_{h}$ is defined as the unit loading on one person:

$$
E_{h}=\frac{q_{i}^{p}}{H}
$$

where:

$N \quad$ - the population exposed to a polluted environment

Eco capacity as Eco-intensity indicates the relative load of negative effects on humans and the environment.

4. Resource capacity sets the amount of resources consumed per unit of output:

$$
R_{c}=\frac{r_{i}}{v_{i}}
$$

where:

$r_{i} \quad$ - the amount of resources consumed in the production process.

So, the overall indicator of Eco-intensity can be calculated as the ratio of total air emissions, waste production and consumption, the volume of contaminated wastewater generated in the area until an appropriate contribution to gross domestic product:

$$
E_{u}=\frac{Q_{i}^{\alpha}+Q_{i}^{\beta}+Q_{i}^{o}}{G_{i}}
$$

where:

$E_{u} \quad$ - the intensity of waste formation in the $i$-industry, $\mathrm{t} \mathrm{mln}^{-1}$

$Q_{i}^{\alpha} \quad$ - harmful emissions into the atmosphere of the $i$-industry, $t$

$Q_{i}^{\beta} \quad$ - wastewater $i$-industry, that contain contaminants, $\mathrm{t}$

$\mathrm{Q}_{i}^{0} \quad$ - production waste; $i$-industry, $\mathrm{t}$

$G_{i} \quad$ - the industry's contribution to gross domestic product, million

The generalized indicator of "Eco-intensity" $E_{s}$ is defined as the total volume of pollution produced by all kinds of production and economic activity of a region for the year gross domestic product in constant prices:

$$
E_{s}=\frac{\sum_{i=1}^{n}\left(Q_{i}^{\alpha}+Q_{i}^{\beta}+Q_{i}^{o}\right)}{G R P}
$$

The generalized indicator of "Eco capacity" territory / region is calculated as the ratio of the total of all types of pollution in the region, total population, i.e. determined by the average environmental load that concerns one person. If you want to set the degree of intraregional differentiation of these indicators, the calculation is carried out according to the same indicators, but 


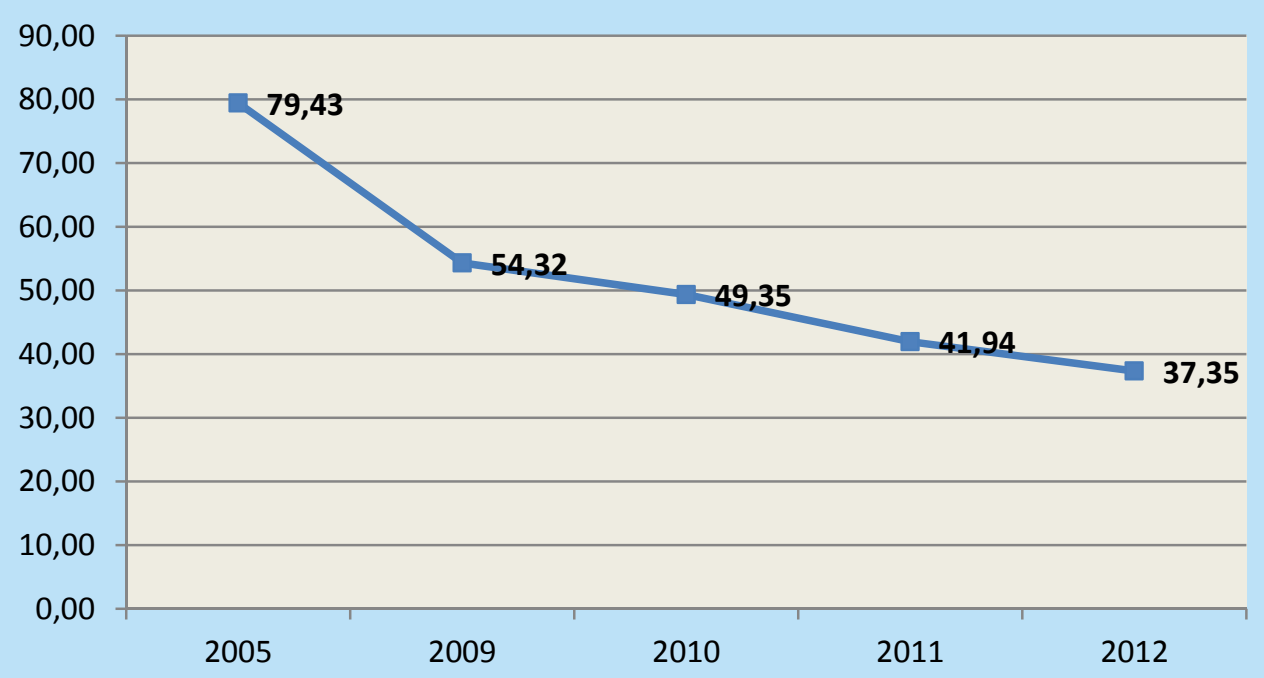

Figure 2 Eco-intensity of air pollution in Ukraine in million tons

Source: formed by the authors on the basis of the State Statistics Service of Ukraine

within the administrative-territorial formations of a region.

Partial indicators of Eco-intensity are determined by the contribution of each type of pollution of the atmosphere, waste and wastewater in the gross national product (relevant to the country as a whole) or gross regional product (relevant to the region), and "Eco capacious" - according to the influence on humans and on environment.

According to S. Bobyliov, natural capacity is an important indicator of efficiency of functioning of natural-food system. This figure is well characterized by the type and level of ecological and economic development (Bobylev and Zakharov, 2012).

Research evaluation of quality indicators of socio-economic development at regional level has its own specificity, especially for areas with environmental regulations (Bilorus, 2005).

The problem of finding the right ways for the sustainable development with the aim to preserve the unique natural objects is reflected in many works of Ukrainian scientistseconomists (Danilishin et al., 1999; Bilorus, 2005; Granovska, 2008; Khlobystov, 2008 and others). However, the research is directed to the analysis and quality evaluation balanced with socio- economic development of the territory with the help of indicators which characterize features of the existing relationship in ecological-socialeconomical system of the region with the aim of identifying priorities and criteria development, which is becoming increasingly popular.

To relate the efficiency of economic activity and the level of its impact on the natural environment, you should determine how big is the intensity of the pollution of the main types of production placed in the region, and how ambiguous is the contribution of existing enterprises in the existing scale of pollution in the environment (Kachala and Berezina, 2014).



Figure 3 Air pollution Eco-intensity in regions in 2012 in million tons

Source: formed by the authors on the basis of the State Statistics Service of Ukraine 
Table 1 Indicators of Eco-intensity of the Ukrainian economy (due to the emissions of pollutants and carbon dioxide into the atmosphere), 2012

\begin{tabular}{|c|c|c|c|c|c|}
\hline & \multirow[t]{2}{*}{$\begin{array}{c}\text { GDP in } \\
\mathrm{mln} \text {. dollars }\end{array}$} & \multicolumn{2}{|c|}{$\begin{array}{l}\text { Emissions of harmful pollutants and carbon dioxide to the } \\
\text { atmospheric air from stationary pollution sources by types } \\
\text { of economic activity in } 2012 \text { in thousand tons }\end{array}$} & \multicolumn{2}{|c|}{$\begin{array}{l}\text { Eco-intensity of economy } \\
\text { in } \mathrm{t} \mathrm{mln} .^{-1} \text { dollars }\end{array}$} \\
\hline & & harmful pollutants & carbon dioxide & harmful pollutants & carbon dioxide \\
\hline Agriculture, hunting, forest management & 33588.6 & 82 & 918.3 & 2.44 & 27.34 \\
\hline Mining industry & 18505.1 & 882.4 & 4296.8 & 47.68 & 232.20 \\
\hline Processing industry & 122916.4 & 1272.5 & 81908 & 10.35 & 666.37 \\
\hline Production and distribution of electricity, gas and water & 18102.5 & 1882.7 & 105752.9 & 104.00 & 5841.89 \\
\hline Construction industry & 16544.1 & 20.7 & 613.2 & 1.25 & 37.06 \\
\hline Transport and communication activities & 32920.7 & 164.3 & 3886.5 & 4.99 & 118.06 \\
\hline
\end{tabular}

Source: formed by the authors on the basis of the State Statistics Service of Ukraine

Researchers of the World Bank noted that excessive aerosol pollution has a negative effect on people's health, causing respiratory system diseases, aggravation of cardiovascular diseases and it may cause premature death. Their assessment was conducted in 18 cities in Eastern and Central Europe, assuming significant excess of the aerosols content in the atmospheric air. The obtained results of this study showed that the decreasing concentration of dust and soot in the air of these cities to the maximum standards adopted by the European Union annually would save the 18,000 people's lives and get 1.2 billion dollars income due to the morbidity reduction and the associated loss of working time (Urbanization and Pollution of air in the garden, 2010).

In Ukraine, about 7 million tons of different substances, hazardous to humans and other living organisms, annually get into the air pool. It causes damage to property (buildings, structures, pavement, etc.) and large economic losses. For example, according to the official data of the State Statistics Committee of Ukraine, 6821.1 thousand tons of harmful substances were found in the environment in 2012 (State Statistics Service of Ukraine, 2014). Although in recent years there has been some fluctuation in the values of this index, the steady trend towards a reduction in emissions has been observed.

Eco-intensity indicator of Ukraine economy for the period from 2005 till 2012 according to the emissions of pollutants into atmospheric air from stationary and mobile sources of pollution (Emissions of pollutants into the air from stationery and movable pollution sources) decreases (Figure 2), which is associated mainly with the reduction of the production enterprises level, which were the main air pollutants.

According to the calculations, the following regions of Ukraine as Kirovohradskiy, Ternopilskiy, Zakarpatskiy, Chernihivskiy have the highest level of Eco-intensity, although they have the lowest volume of gross regional product in 2012. Moreover Dnepropetrovskiy region have the highest level of Eco-intensity, and it is characterized by high levels of industrial development (Figure 3).

In general we can say that Eco-intensity reduction has some positive aspects in the improvement of the ecological situation and in the decrease of anthropogenic loads, as the important factor here is the production, which concerns changes in the dynamics of macroeconomic indicators (output).

The main pollutants in Ukraine are enterprises which produce and distribute electricity, gas and water, which accounts for $45 \%$ of emissions (excluding carbon dioxide). Enterprises of the same industry account for $54 \%$ of carbon dioxide emissions that may cause the negative effect of climate changing. Some $30 \%$ of pollutants and $42 \%$ of carbon dioxide are emitted into the atmosphere from facilities processing industry (enterprises of ferrous metallurgy, chemical, oil refining, oil and gas industries, cement production) (State Statistics Service of Ukraine).

The estimated data of emission intensity of pollutants and carbon dioxide due to the types of economic activity have shown that the highest values were the production and distribution of energy (harmful pollutants $104 \mathrm{t} \mathrm{mln}^{-1}$, for carbon dioxide $-5841.89 \mathrm{t} \mathrm{mln} .^{-1}$ ), mining industry (harmful pollutants $-47.68 \mathrm{t} \mathrm{mln} .^{-1}$, for carbon dioxide $-232.2 \mathrm{t} \mathrm{mln}^{-1}{ }^{-1}$, processing industry (harmful pollutants $-10.35 \mathrm{t} \mathrm{mln.}^{-1}$, for carbon dioxide -666.37 t mln..$^{-1}$ (Table 1).

In Ukraine, the conservation measures for the reduction of hazardous substances into the atmosphere are being implemented. Thus, the domestic enterprises have spent 4671.9 million of UAH for the implementation of 449 environmental measures to protect the atmosphere and climate change mitigation in 2012. Among them we can define the improvement of technological processes; construction and commissioning of new gascleaning installations and structures; improving the efficiency of existing wastewater treatment plants due to their modernization, renovation and repair; elimination of pollution sources. In 2012, it helped to reduce the amount of hazardous substances in air pool by 146.9 thousand tons, however, the difficult situation in the sphere of atmospheric air protection indicates a lack and low efficiency of such measures (Law of Ukraine, 2000).

\section{Conclusions}

The purpose of sustainable development of a region is the quality of people's lives, preserved nature and prosperous economy. The process of achieving the goals of sustainable development, management and regulation of this process, effective evaluation of the used measures can be possible under conditions of creating corresponding systems of indicators. The integral indicators of sustainable development allow us to characterize state economy changes, social sphere and environment in time and space. In order to improve the quality of people's lives and making the society more stable, it is necessary to find and keep a balance between the needs, the problems of economic development and opportunities of the environment. Therefore, one of the main tasks that can be solved through the use of indicators in practice is the determination of changes of state of one or another sphere with regard to possible directions for future work. So, the main advantages of LEDs are that they allow us to assess the situation, its change in positive or negative direction; give time to adjust the integral development of the system.

In the research, the study of the indicators of Eco-intensity in dynamics has proved the quality of economic development of a region as a whole due to individual activities / sectors. It also gives the opportunity to compare 
industry due to the level of anthropogenic load on the environment and conduct inter-regional analysis. For government agencies, this information concerns industries that define strategic directions for economic development of a region and welfare increase of population. This enables us to determine the most problematic places that primarily require taking preventive measures and making management decisions.

\section{References}

BEREZINA, O. - CHEREVKO, 0. 2014. Regional policy priorities of socio-economic development. In Scientific Papers of Cherkasy State Technological University. Series: Economics, vol. 36, 2014, part III, p. 147-152.

BILORUS, 0. 2005 Global perspective and sustainable development: system marketing research. K.: AIDP, $2005.492 \mathrm{pp}$.

BOBYLEV, S. - ZAKHAROV, V. 2012. Eco-Economic Bases of sustainable development. In Green Economy and Modernization. Economic and Environmental estimation of sustainable development. Available at: http://www.ecopolicy.ru/upload/File/ Bulletins/B_60.pdf

CALCULATING ECO-EFFICIENCY INDICATORS. A Workbook for Industry. Available at: http:// www.indeco.com/files.nsf/Lookup/NRTEE-Ecoefficiency-Workbook/\$file/NRTEEEcoefficiency-Workbook.pdf

DANILISHIN, B. et al. 1999. Natural potential resource for sustainable development of Ukraine. Kyiv : Ukraine RVPS, 1999.716 pp.

GRANOVSKA, L. 2008. Theoretical study of integrated Environmental Assessment in a regional context. In Collected Works of Lutsk National Technical University. Series: Regional economics. Lutsk : LNTU, vol. 5, 2008, no. 17, p. 265-278.

FESYANOV, P. 2011. State regulation ensuring environmental safety: the experience of the leading countries. In Bulletin of the National Academy of Public Administration under the President of Ukraine, 2011, no. 4, p. 142-150.
FRAMEWORK FOR THE DEVELOPMENT OF ENVIRONMENT STATISTICS (FDES). 2013. Available at: http://unstats.un.org/unsd/statcom/doc13/BG-FDES-Environment.pdf

KACHALA, T. - BEREZINA, 0. 2014. The investment attractiveness of Ukraine: opportunities and risks for foreign investment. In EuroMed Journal of Business : The Future of Entrepreneurship. Kristiansand : EuroMed Press, 2014. p. 749-758.

KATES, R. - PARRIS, T. - LEISEROWITZ, A. 2005. What is sustainable development? Goals, indicators, values, and practice by. Available at: http://www.hks.harvard.edu/sustsci/ ists/docs/whatisSD_env_kates_0504.pdf

KHLOBYSTOV, E. - CHERNOFVA T. 2008. Sustainable development through Ukraine methodological reflection globalization. In Science Bulletin, vol. 18, 2008, no. 12, p. 121-131.

LAW OF UKRAINE State program of national ecological network in Ukraine for 2000-2015. September 21, 2000 № 1989-III. Available at: http://zakon1.rada.gov.ua/cgi-bin/ laws/main.cgi

STATE STATISTICS SERVICE OF UKRAINE. Available at: http://www.ukrstat.gov.ua.

SYSTEM OF ENVIRONMENTAL-ECONOMIC ACCOUNTING (SEEA). Available at: http://unstats. un.org/unsd/envaccounting/seea.asp

URBANIZATION AND POLLUTION OF AIR IN THE GARDEN. Available at: http://www. worldbank.org/depweb/beyond/wrru/wnr_10.pdf.

\section{Contact address:}

Olena Berezina, Ph. D. (Economics), Associate Professor, As. Prof. of Management Department, Cherkasy State Technological University, Cherkasy, Ukraine, e-mail: olenaberezina@mail.ru 